\title{
Infographic of Indonesian Food History in Reading Classes: Focusing on Students' Perspectives and Reading Enactment
}

\author{
Ari Ambarwati*1, Sri Wahyuni' ${ }^{1}$, Susi Darihastining ${ }^{2}$ \\ Universitas Islam Malang, Malang, Indonesia \\ STKIP Jombang, Indonesia \\ Email corresponding author: ariati@unisma.ac.id
}

\begin{abstract}
Anchored by scant empirical research on the use of infographics of Indonesian food history in reading classes, this study seeks to explore how students as learning actors perceive this infographic learning enactment and to what extent their reading motivation evolves. To obtain data, seventy-five Indonesian secondary school students were recruited to respond to a Likert-scale questionnaire. Their answers were analyzed in percentages. Besides, ten of the participants were invited for brief interviews. Findings suggest that the students held positive perceptions of the use of infographics in their reading classes. Besides, their reading motivation rises through their knowledge construction on the diversity of food in Indonesia. This study offers pedagogical implications for classroom practices.
\end{abstract}

Keywords: Infographic, Indonesian food history, reading class, students' perspective

\section{INTRODUCTION}

This study is part of a larger research project on the development of an infographic as a reading enactment explaining Indonesian food history for secondary school students. The focus of this study is to unveil how the students view the infographic use in their reading classes. Although many studies have discussed the effective use of infographics in educational contexts, little attention has been directed to investigate the students' viewpoints as learning actors. Besides, very sparse classroom practices are conducted to include a topic of Indonesian food history in reading classes. Thereby, these rationales support the exploration of this issue.

As one of the agricultural countries, Indonesia possesses a variety of food throughout the country (Colozza \& Avendano, 2019). This array is generated from cultural assimilation among Indonesians and international people who inhabited the islands of Indonesia, particularly from Arab and Malay. This assimilation brings about the creation of new food and the histories that later culturally embed in Indonesia from generation to generation. Practically, this cultural assimilation also portrays how ethics, aesthetics, and values of a culture are emerged in food variety (Eidinow, 2016). However, among the many encounters with international food in Indonesia, a decrease in understanding Indonesian food history rises gradually (Rachmi et al., 2018). Recent research shows no pedagogical attempts are made by the government through the Ministry of Education (MoE) to introduce food history to students in the schooling sectors. It, consequently, adds to the decrease in knowledge, attitude, and passion about knowing the issue as a local identity construction (Prasetyo et al., 2019). In this work, the effective use of an infographic as a learning enactment to raise the students' awareness of Indonesian food history is analyzed from students' perspectives.

Recently, infographics have been extensively used in different contexts, such as in nursing education (Chicca \& Chunta, 2020), medical literature (Martin et al., 2019), curriculum integration (Lee \& Cavanaugh, 2016), and higher education (Hsiao et al., 2019). The studies proved that infographic use creates effective and quick understandings for students in their classroom practices. 
Although constraints such as teacher knowledge may hinder the practice of infographics in classrooms, the students could learn autonomously and construct their understanding of specific topics discussed by using infographics (Young et al., 2019). To the best of our scholarly knowledge, the use of infographics remains an under-researched issue in educational contexts. Despite this, we attempt to explore the use of infographics from the lens of students' perspectives on understanding Indonesian food history. Understanding students' perspectives on a particular teaching and learning enactment is also challenging for scholars since perspectives, including attitudes, voices, and beliefs, significantly correlate with learning motivation (Ghaith, 2002). Although students' perspectives are essential in learning, little empirical research is geared to explore this issue in the context of Indonesian schooling sectors. In fact, studies mainly focus on developing teaching strategies and media for classroom practices (Anam \& Stracke, 2016; Hidayati \& Wuryandari, 2012).

Informed by scant studies on the interlink of students' perspectives, infographics, and Indonesian food history, this study was carried out to generate understandings on how Indonesian secondary school students view the use of infographics explaining Indonesian food history in their reading classes. For these reasons, the study is guided by two research questions: 1) to what extent do the students perceive the effective use of infographics in their reading classes and 2) to what extent does their reading motivation evolve after reading the infographic.

\section{METHOD}

This study employed a Likert-scale questionnaire to generate data from participants. Since this is part of a larger study, the questionnaire was taken from need analysis instrument. Seventy-five Indonesian secondary school students spread out in West Java, West Nusa Tenggara, and East Java provinces were recruited to answer eight questions in the questionnaire. Additionally, ten of the participants were invited for brief interviews. Previously, they engaged in a learning enactment employing infographic that has been developed for reading class activity. The topic covered in the infographic was Indonesian food history. Therefore, the questionnaire attempted to explore their perspectives on using the infographic during the class.

The data were then analyzed in percentages. We divided the students' answers into percentages of Strongly Agree (SA), Agree (A), Moderate Agree (MA), and Disagree (D). The brief interviews held at the same time they fulfilled the questionnaire. The interviews conducted to find out the clear students' motivation for reading infographics of Indonesian food history. The interview also tries to reveal the specification infographics preferred by the students, especially in the subject of Indonesian food history.

\section{FINDINGS AND DISCUSSION}

This study explores the perspectives of Indonesian secondary school students on the use of infographics in their reading classes and the evolvement of their reading motivation. Eight questions delivered to the respondents to construe their opinions, perceptions, and preferences on the infographic of Indonesian food history. To understand these questions, Table 1 presents data from the questionnaire. 
Table 1. Questionnaire responded by the students

\begin{tabular}{|c|c|c|c|c|c|c|}
\hline \multirow[t]{2}{*}{ No } & \multirow[t]{2}{*}{ Questions } & \multicolumn{4}{|c|}{ Percentage Classification } & \multirow[t]{2}{*}{ Total } \\
\hline & & $\begin{array}{l}\text { Strongly } \\
\text { Agree } \\
\text { (SA) }\end{array}$ & $\begin{array}{l}\text { Agree } \\
\text { (A) }\end{array}$ & $\begin{array}{l}\text { Moderate } \\
\text { Agree } \\
\text { (MLA) }\end{array}$ & $\begin{array}{l}\text { Disagree } \\
\text { (D) }\end{array}$ & \\
\hline 1 & Infographics raise students' & $16 \%$ & $44.6 \%$ & $30.3 \%$ & $8.9 \%$ & $911 \%$ \\
\hline 2 & $\begin{array}{l}\text { Colors and informed-tests in } \\
\text { infographics are appealing for } \\
\text { reacing }\end{array}$ & $25 \%$ & $39.2 \%$ & $26.7 \%$ & $8.9 \%$ & $911 \%$ \\
\hline 3 & $\begin{array}{l}\text { Infographics accessbble through } \\
\text { mobile phone are interesting for } \\
\text { reading activity }\end{array}$ & $23.2 \%$ & $26.7 \%$ & $41 \%$ & $8.9 \%$ & $91.1 \%$ \\
\hline 4 & $\begin{array}{l}\text { History hooviedge presented in } \\
\text { Infographics are essential }\end{array}$ & $26.7 \%$ & $37.5 \%$ & $26.7 \%$ & $8.9 \%$ & $91.1 \%$ \\
\hline 5 & $\begin{array}{l}\text { Indonesian food history } \\
\text { presented in infographiss could } \\
\text { raise students' reading } \\
\text { motivation }\end{array}$ & $35 \%$ & $40 \%$ & $22.5 \%$ & $2.5 \%$ & $97.5 \%$ \\
\hline 6 & $\begin{array}{l}\text { Infographics presenting } \\
\text { Indonesizn food history assists } \\
\text { students to understand food array }\end{array}$ & $38 \%$ & $42 \%$ & $10 \%$ & $5 \%$ & $95 \%$ \\
\hline 7 & $\begin{array}{l}\text { Infographics presenting } \\
\text { Indonesian food history assists } \\
\text { students to understand food } \\
\text { potentials and cultures in } \\
\text { Indoneaia }\end{array}$ & $25 \%$ & $35.7 \%$ & $33.9 \%$ & $5.3 \%$ & $94.7 \%$ \\
\hline 8 & $\begin{array}{l}\text { Infographics accessed in a } \\
\text { mobile phone are appealing }\end{array}$ & $17.8 \%$ & $42.8 \%$ & $30.7 \%$ & $7.1 \%$ & $92.9 \%$ \\
\hline
\end{tabular}

The findings of this study portray that the students prefer the infographic format that combines various forms of visualization with sufficient text as reading material. Infographic visualization that presents information, data, and knowledge in pictures in the form of pictograms and other illustrations with attractive colors leads to students' reading motivation. According to Dubovi (2019), Sedrakyan et al., (2019), and Schneider et al., (2018), the visualization of information provided by infographics is more readable, more comfortable to remember, managed, and promoted to readers. It is depicted in the interviews with Ana, Mei, and Habib (pseudonym). They shared that:

\section{Excerpt 1:}

"This infographic is comfortable for reading, and also interesting. It presents many pictures. If Indonesian food history is presented in an infographic, I would prefer reading it because I want to know the history." (Ana)

\section{Excerpt 2:}

"With an infographic, I become interested in reading. It contains many pictures and brief explanations.” (Mei).

\section{Excerpt 3:}

"In my opinion, infographic promotes reading more enjoyable. I would like to read more if the texts are infographics." (Habib)

The infographic containing Indonesian food history develops the students' understanding of food diversity. Knowledge of Indonesian food history can be made in a narrative infographic format. It corresponds to research carried out by (Damman et al., 2018), suggesting that narrative infographics are effective in introducing narration and stories in the presentation of data 
visualization. In this study, Indonesian food history is the central theme presented in the infographic. Historical knowledge in reading texts and non-text lessons in schooling sectors remain decontextualized, presenting more text composition than visualizations.

Textbooks and non-text lessons in schools have not used exclusively infographic media to present historical texts, especially food history texts. In the reading activity at the School Literacy Movement in high school, the reading material used is still in the form of printed books available on each bookshelf in each student's classroom. Reading material that can be accessed on cell phones, laptops, and computers have not been used to its full potential in reading activities. The findings of this study confirm that reading material in the form of infographics containing Indonesian food history that can be accessed in gadgets is essential in developing reading activities since it leads students to the potential and cultural existence of Indonesian food array (Agusta \& Ramadin, 2016). It is seen from the excerpts of Maura, Lusi, Rizal, and Fero. They contended that:

Excerpt 4:

"It is very interesting. Actually, I don't like learning history. But I now love learning it with an infographic." (Maura)

Excerpt 5:

"The content can be understood easily. It is interesting. More colors inside the infographic." (Lusi)

Excerpt 6:

"I wish I have more infographics on School Literacy Movement activity. History in infographic could not be more anymore, Perhaps." (Rizal).

Excerpt 7:

"Indonesian food history on infographic sounds challenging. I think I should read it since infographic contains more interesting illustrations and pictures." (Fero).

Rice history is situated into the infographic media and placed at the top as a central topic. The history of rice tells about the origin of rice, which is thought to originate from the river Ganges, Brahmaputra, and Yangtse river valleys. Besides, the anatomy of rice, rice myths, processed rice, and various types of rice in Indonesia is put following the main topic. These infographics are made in portable network graphics (PNG) format. This PNG format can be easily uploaded and downloaded on mobile phones in an information storage unit of 4.9 megabytes. Infographic accessibility in student devices is an important issue since it develops students' reading motivation. In the interview, Emy, Laura, and Iban shared that:

Excerpt 8:

"I like learning food history when it is presented in an infographic, which is accessible through mobile phones." (Emy).

Excerpt 9:

"It is easy and interesting to read food history in the form of infographics on a mobile phone." (Laura). 


\section{Excerpt 10:}

"Reading material accessed from the gadget always practical. I could access it anytime, moreover, in infographic form." (Iban).

Infographics and data visualization are excellent tools that present information systematically, provide critical concepts about a topic, and can influence and guide the reader, creating infographics requires adequate knowledge about the reader profile, content, infographic specifications, and how to communicate information to the reader. The identification of students' needs and preferences for the infographics of Indonesia's staple food history, which is done by the author, is a method for obtaining information on the content and characteristics of infographics needed by students. The identification results inform that $91.1 \%$ of students agreed that historical knowledge was displayed in infographic form.

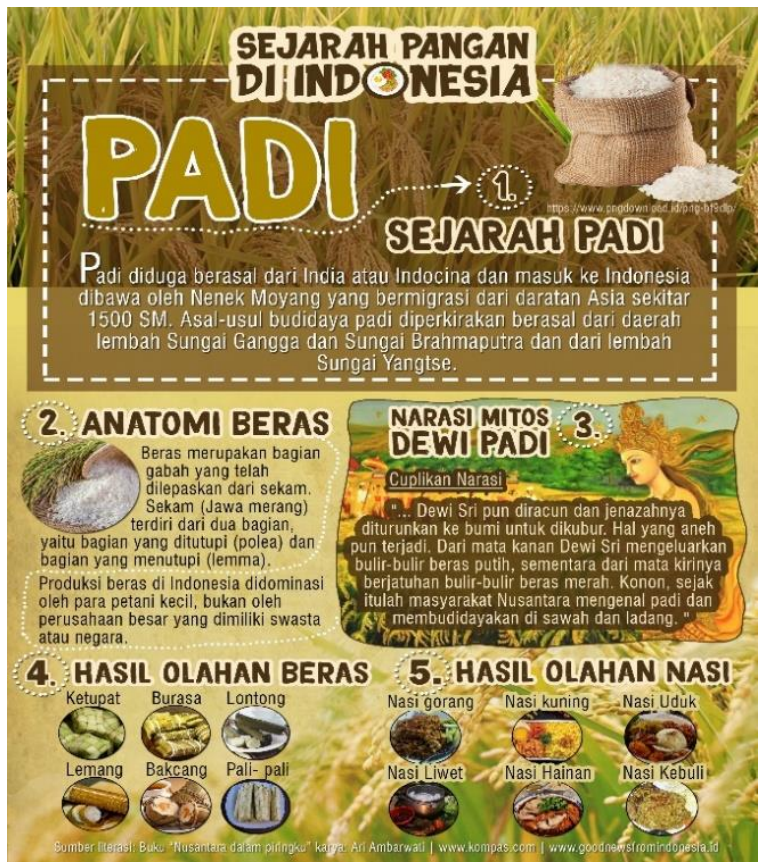

Figure 1. History infographic of rice

Rice history infographics contain four pieces of information. The first is information about the history of rice entry into Indonesia, the anatomy of rice, stories, and myths about rice, and processed rice or rice. Four information was made with the consideration that $94.7 \%$ of students agreed to the statement that the infographic history of Indonesia's staple food made them more careful about the potential and food culture of Indonesia. Indonesian food culture includes processed rice, such as rice cake, burasa, rhombus, and others. As the main staple food, rice has relatively many types of processed foods such as fried rice, yellow rice, uduk rice, and so on. The diversity of rice food preparations owned by various tribes in Indonesia shows that the knowledge of processing staple foods into a variety of dishes includes traditional knowledge and technology in food processing. Traditional knowledge and technology are two of the ten objects of cultural advancement, which include oral traditions, manuscripts, customs, rites, traditional knowledge, traditional technology, arts, languages, folk games, and traditional sports. 


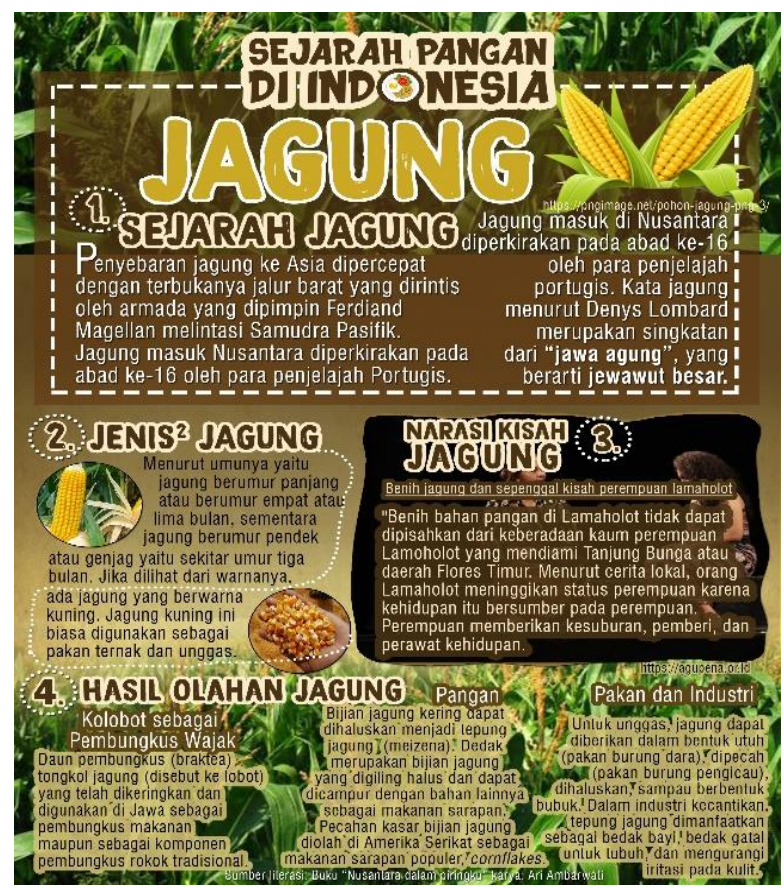

Figure 2. History infographic of Corn

Historical infographics of corn are narrated at the beginning and placed in the top position. The history of corn contains information about the entry of corn into Indonesia, which was brought by Portuguese explorers in the 16th century (Ambarwati, 2019). Information presented in the infographic media after the history of corn is the types of corn, narrative stories of corn from Lamaholot, East Nusa Tenggara, and processed corn. Corn is the leading food other than rice mentioned in Serat Centhini (Wang et al., 2019). Corn is said to occupy the position as the main staple food along with rice, and even there has been mention of corn rice and corn rice. This proves that corn is a staple food that is familiar and has been widely consumed, especially by Javanese people in the 19th century. The processed corn, including corn husk, is also described. Corn skin functioned as food wrappers and traditional cigarette wrappers. Corn can also be processed as a modern food such as corn chips or produced as animal feed and baby powder.

The infographic text of the history of corn is made more with the consideration that corn is not only widely used as human food, but also the main food consumed by livestock, and the main ingredient in the beauty industry. This information is essential given that $95 \%$ of students agree with the statement that infographics containing the history of Indonesia's staple food on cellphones/tablets/laptops/computers will help them understand Indonesia through its food diversity. The positive perspective of students on food history infographics confirms the findings of (Hsiao et al., 2019) who formulate their conclusions that infographic contributions to students include the enduring knowledge (content) obtained, participation and active student interest, time effectiveness, reading content becomes more concrete, generating students 'creative ideas for the subject being read, and activating students' visual and verbal processing channels, which reinforces meaningful learning. 


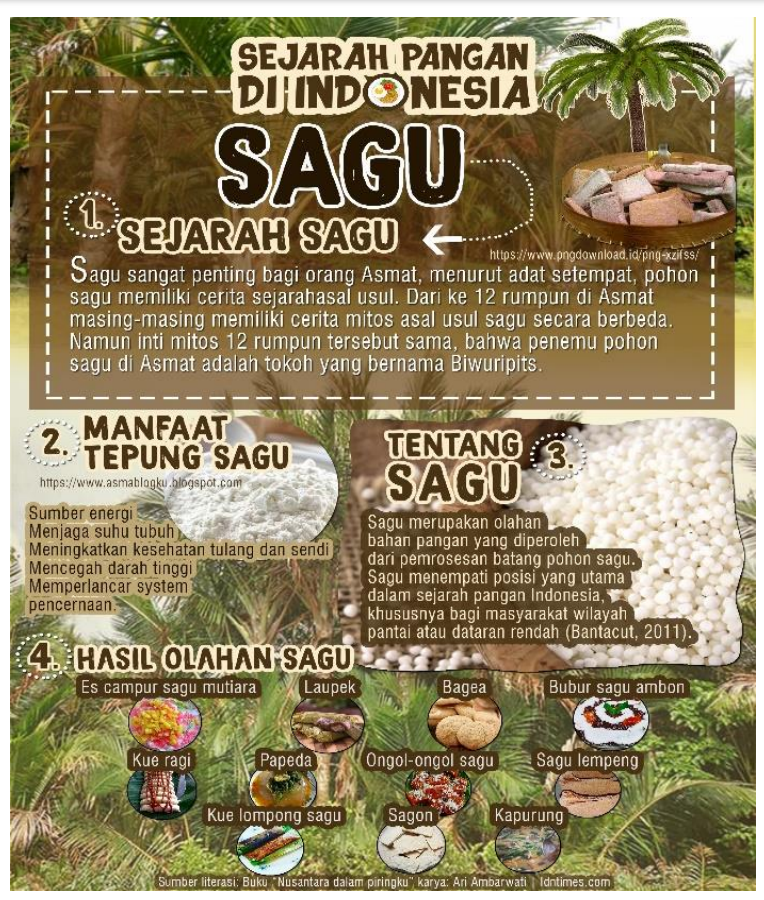

Figure 3. History Infographic of sago

The sago historical infographics describe that sago is a food source from the land of Papua. Biwiripits is a figure believed to give birth to sago in the myths of the Papuan people (Ambarwati, 2019). In addition to the history of sago, the history of sago history presents text about the benefits of sago flour, characteristics of sago, and processed sago. The three carbohydrate-producing foods are staple foods that are popular and widely consumed by the people of Indonesia. Rice occupies a strategic position. Indonesian rice production in January-September 2018 reached 32.42 million tons, while the total rice consumption of the Indonesian people in the same period was 29.57 million tons. The data prove that the dependence of Indonesian people on rice is very high, even though Indonesia has other non-rice staple foods such as corn, tubers, sago, and bananas.

The infographic uses rich color visualization, sufficient text, by combining narrative and quantitative data. This narrative infographic prototype forms the basis to develop reading models that can be used sustained reading activities. According to Locoro et al. (2017), infographics must have three fundamental aspects such as visual, knowledge about content, and stories. The narrative infographic prototype in this research was made by considering three main points, namely the results of the analysis of respondents' needs obtained through questionnaires, references on narrative infographics and infographics, as well as the history of Indonesia's staple food accessed in student and school devices, so students can read, review, and produce writings based on narrative infographics of Indonesia's staple food history in its reading activities.

In the context of Indonesia, which consists of various tribes, the facilitation of food literacy in reading is an appropriate way to develop communication, both within the scope of one tribe and between tribes. Morgan et al. (2020) mention that language through communication skills was also developed to reduce tension in the distribution of food, including staple foods since ancient times. This is referred to as conviviality today is a practice that has been carried out by Homo Erectus in groups, when sharing food around the campfire, making eye contact, sitting side by side, smiling, laughing, and talking to each other. Exposing the history of Indonesia's staple foods to developing 
reading activities can help high school students understand cultural diversity, which accompanies the practice of glorifying the staple foods of Indonesian people.

\section{CONCLUSION}

This study has attempted to explore students' perspectives on the use of infographics of Indonesian food history and to what extent their reading motivation rises after reading the materials from infographics. Perceptions were found positive, and the students' reading motivation evolves through their understanding of Indonesian food diversity. This knowledge leads to sustained motivation in the students' reading classes. The critical aspect that emerged in the use of infographics is its visualized information. Students found it easier to understand history through visual texts. Therefore, the findings of this study could be learning catalysts for teachers to employ infographics in reading classes. Although our research has unveiled perspectives and reading motivation through a Likert-scale questionnaire, future works are encouraged to employ a qualitative approach in the forms of classroom observation. This is necessary since qualitative inquiry captures naturally occurring phenomena.

\section{ACKNOWLEDGMENT}

Our sincere thanks are addressed to M. Faruq Ubaidillah, Tim Percepatan Publikasi, Universitas Negeri Malang, Indonesia, for his insightful feedback on the earlier version of this paper. Since it is part of a larger research project entitled, "Infografik Audivi Gastronomi Indonesia sebagai Bahan Bacaan Gerakan Literasi Sekolah (Indonesian Gastronomic Audiography Infographics as Material for Reading School Literacy Movements," we would also thank for the funding supports from Institute of Research and Community Services, Universitas Islam Malang, Indonesia.

\section{REFERENCES}

Ambarwati, A. (2019). Nusantara dalam Piringku (Archipelago on my hand). Gramedia Pustaka Utama: Jakarta.

Agusta, B., \& Ramadin, T. Y. (2016). Influence of Infographic on Exhibition Space Towards The Level of Interest, Understanding, and Visitors Behavior(Case Study: Educational Exhibition on Implementation of Nuclear Power Plant Project). Proceedings of the 1st UPI International Conference on Sociology Education (UPI ICSE 2015). 1st UPI International Conference on Sociology Education, Bandung, Indonesia. https://doi.org/10.2991/icse15.2016.99

Anam, S., \& Stracke, E. (2016). Language learning strategies of Indonesian primary school students: In relation to self-efficacy beliefs. System, 60, 1-10. https://doi.org/10.1016/j.system.2016.05.001

Chicca, J., \& Chunta, K. (2020). Engaging Students with Visual Stories: Using Infographics in Nursing Education. Teaching and Learning in Nursing, 15(1), 32-36. https://doi.org/10.1016/j.teln.2019.09.003

Colozza, D., \& Avendano, M. (2019). Urbanisation, dietary change and traditional food practices in Indonesia: A longitudinal analysis. Social Science \& Medicine, 233, 103-112. https://doi.org/10.1016/j.socscimed.2019.06.007 
Damman, O. C., Vonk, S. I., van den Haak, M. J., van Hooijdonk, C. M. J., \& Timmermans, D. R. M. (2018). The effects of infographics and several quantitative versus qualitative formats for cardiovascular disease risk, including heart age, on people's risk understanding. Patient Education and Counseling, 101(8), 1410-1418. https://doi.org/10.1016/j.pec.2018.03.015

Dubovi, I. (2019). Online Computer-Based Clinical Simulations: The Role of Visualizations. Clinical Simulation in Nursing, 33, 35-41. https://doi.org/10.1016/j.ecns.2019.04.009

Eidinow, E. (2016). Telling stories: Exploring the relationship between myths and ecological wisdom. Landscape and Urban Planning, 155, 47-52. https://doi.org/10.1016/j.landurbplan.2016.04.014

Ghaith, G. M. (2002). The relationship between cooperative learning, perception of social support, and academic achievement. System, 30(3), 263-273. https://doi.org/10.1016/S0346251X(02)00014-3

Hidayati, N., \& Wuryandari, A. I. (2012). Media Design for Learning Indonesian in Junior High School Level. Procedia - Social and Behavioral Sciences, 67, 490-499. https://doi.org/10.1016/j.sbspro.2012.11.354

Hsiao, P. Y., Laquatra, I., Johnson, R. M., \& Smolic, C. E. (2019). Using Infographics to Teach the Evidence Analysis Process to Senior Undergraduate Students. Journal of the Academy of Nutrition and Dietetics, 119(1), 26-30. https://doi.org/10.1016/j.jand.2017.10.022

Lee, J. W., \& Cavanaugh, T. (2016). Building your brand: The integration of infographic resume as student self-analysis tools and self-branding resources. Journal of Hospitality, Leisure, Sport \& Tourism Education, 18, 61-68. https://doi.org/10.1016/j.jhlste.2016.03.001

Locoro, A., Cabitza, F., Actis-Grosso, R., \& Batini, C. (2017). Static and interactive infographics in daily tasks: A value-in-use and quality of interaction user study. Computers in Human Behavior, 71, 240-257. https://doi.org/10.1016/j.chb.2017.01.032

Martin, L. J., Turnquist, A., Groot, B., Huang, S. Y. M., Kok, E., Thoma, B., \& van Merriënboer, J. J. G. (2019). Exploring the Role of Infographics for Summarizing Medical Literature. Health Professions Education, 5(1), 48-57. https://doi.org/10.1016/j.hpe.2018.03.005

Morgan, L., Delehanty, A., Cleary Dillon, J., Schatschneider, C., \& Wetherby, A. M. (2020). Measures of early social communication and vocabulary production to predict language outcomes at two and three years in late-talking toddlers. Early Childhood Research Quarterly, 51, 366-378. https://doi.org/10.1016/j.ecresq.2019.12.005

Prasetyo, Y. B., Kurnia, A. D., Masruroh, N. L., Nursalam, N., Hargono, R., Ahsan, A., \& Kumboyono, K. (2019). Factors influencing promotive behaviours in mothers of Indonesian children with avoidant restrictive food intake disorder. Journal of Taibah University Medical Sciences, 14(5), 454-459. https://doi.org/10.1016/j.jtumed.2019.07.003

Rachmi, C. N., Hunter, C. L., Li, M., \& Baur, L. A. (2018). Food choices made by primary carers (mothers/ grandmothers) in West Java, Indonesia. Appetite, 130, 84-92. https://doi.org/10.1016/j.appet.2018.08.005

Schneider, S., Beege, M., Nebel, S., \& Rey, G. D. (2018). A meta-analysis of how signaling affects learning with media. Educational Research Review, 23, 1-24. https://doi.org/10.1016/j.edurev.2017.11.001 
Sedrakyan, G., Mannens, E., \& Verbert, K. (2019). Guiding the choice of learning dashboard visualizations: Linking dashboard design and data visualization concepts. Journal of Computer Languages, 50, 19-38. https://doi.org/10.1016/j.jvlc.2018.11.002

Wang, H., Liu, J., Min, W., Zheng, M., \& Li, H. (2019). Changes of moisture distribution and migration in fresh ear corn during storage. Journal of Integrative Agriculture, 18(11), 26442651. https://doi.org/10.1016/S2095-3119(19)62715-2

Young, J., Bridgeman, M. B., \& Hermes-DeSantis, E. R. (2019). Presentation of scientific poster information: Lessons learned from evaluating the impact of content arrangement and use of infographics. Currents in Pharmacy Teaching and Learning, 11(2), 204-210. https://doi.org/10.1016/j.cptl.2018.11.011 